\title{
VIVÊNCIAS DE UMA EQUIPE MULTIPROFISSIONAL DE ATENDIMIENTO PRE-HOSPITALAR MÓVEL EM SUPORTE AVANÇADO DE VIDA NA ASSISTÊNCIA AO ADULTO EM SITUAÇÃO DE PARADA CARDIORRESPIRATÓRIA*
}

\author{
VIVENCIAS DE UN EQUIPO MULTIPROFESIONAL EN LA ATENCIÓN \\ AVANZADA PREHOSPITALARIA MÓVIL AL ADULTO EN SITUACIÓN DE \\ EMERGENCIA CON PARO CARDIORRESPIRATORIO.
}
JANE APARECIDA CRISTINA**, MARIA CÉLIA BARCELLOS DALRI***, REGILENE MOLINA ZACARELI CYRILLO ${ }^{* * * *}$, TOYOKO SAEKI ${ }^{* * * * *}$, EUGENIA VELLUDO VEIGA******

\begin{abstract}
RESUMO
Este estudo de abordagem qualitativa e exploratorio tem como objetivo investigar a vivência da equipe multiprofissional na assistência ao adulto em situação de parada cardiorrespiratória (PCR), numa unidade de suporte avançado (USA) de vida de atendimento pré-hospitalar móvel (APH). Para a coleta de dados foi utilizado a entrevista semi-estruturada que compreendeu questões sobre o perfil sócio-demográfico, profissional e questões norteadoras sobre o tema. A amostra foi constituída por 16 profissionais da USA. Os dados foram organizados por meio da análise de conteúdo proposta por Bardin (1977) identificando-se quatro temas: percepções dos profissionais sobre APH móvel avançado, os sentimentos e emoções dessa equipe frente ao atendimento a PCR, identificação dos agentes estressores no atendimento à PCR e as reações de estresse nessa situação. A equipe multiprofissional relata sua vivência como um serviço desafiante e difícil, diante das situações inesperadas, desconhecidas e angustiantes sendo capazes de perceberem satisfações pessoais e realização profissional. Evidenciaram-se nas demais categorias identificadas as expressões: a necessidade de conhecimento e capacitação técnica, habilidade e agilidade, tomada de decisões, trabalho em equipe, dificuldade em lidar com sofrimento dos familiares, envolvimento emocional, trabalhar em altas temperaturas, dificuldades em lidar com a morte, com sentimentos de impotência, frustração e tristeza. Portanto, a equipe multiprofissional vivencia a possibilidade de sofrimento psíquico justificando a necessidade de promover a reflexão e discussão dos aspectos técnicos, científicos e éticos referentes ao cuidado do paciente em PCR, nas diferentes possibilidades que envolvem essa situação com vistas à melhoria da qualidade do atendimento e do relacionamento interpessoal.
\end{abstract}

Palavras-chave: Pré-hospitalar móvel, equipe multiprofissional, parada cardiorrespiratória, estresse

*Trabalho extraído da Dissertação de Mestrado apresentado na Escola de Enfermagem de Ribeirão PretoUniversidade de São Paulo(EERP-USP)

${ }^{* *}$ Enfermeira do Serviço de Atendimento Móvel de Urgência da Secretaria Municipal da Saúde de Ribeirão Preto - SP. Mestre pela EERP-USP. Email: ja.cristina@uol.com.br

****Enfermeira Doutora Docente na área de Enfermagem Geral e Especializada na EERP-USP.Email: macdalri@ eerp.usp.br

*****Enfermeira Doutoranda do Serviço de Atendimento Móvel de Urgência da Secretaria Municipal da Saúde de Ribeirão Preto - SP. Mestre pela EERP-USP..Email:regizacareli@yahoo.com.br

${ }^{* * * * *}$ Enfermeira Doutora Docente na área de Enfermagem Psquiátrica e Saúde mental na EERP-USP

*******Enfermeira Doutora Docente na área de Enfermagem Geral e Especializada na EERP-USP 


\begin{abstract}
This study of qualitative boarding has as objective investigate the experience of the multi-professional team to assistance a patient in arrest cardiac situation in an advanced unit of life support (USA) and mobile prehospital attendance (APH). The data collection was utilized a semi-structuralized interview that was included questions about the sociodemographic profile and professional and questions directed to the topics studied. The sample was constituted of 16 professionals, of the USA. Data were organized and analyzed the content proposed by Bardin (1977), identifying four topics: perceptions about the APH advanced movable, the feelings and emotions of the multi professional team in front of the attendance to PCR, identification of the stresses agents in the attendance and reactions to the stress in PCR. The multi-professional team relates their experience hard and challenger job of non waiting situations, unknown and overwhelming but also able to percept personal satisfactions and professional realization. It was evidenced too in the others categories the expressions: knowledge and technique training qualification and technologic, ability and agility, taken decisions, group work, the difficult to deal with the familiars, emotional involvement, work in high temperatures, difficult to deal with the death, feelings of incapacitation, frustration and sadness. Therefore this multi-professional team experience daily the real possibility of psychic suffer, this study the necessity that promote moments of reflection and discussion around of the techniques aspects, scientific and ethical referring to the cautions of the critics patients in PCR and of the different possibilities of situations that involve them during the attendance with vision on better quality of the attendance and the interpersonal relation.
\end{abstract}

Keyword: Prehospital mobile, multi-professional, cardio respiratory problems, emergency care, stress

Fecha Recepción: 17 abril de 2006 Fecha Aceptación: 02 septiembre 2008

\title{
RESUMEN
}

Estudio de carácter cualitativo y exploratorio que tuvo como objetivo investigar la vivencia del equipo multiprofesional en la asistencia al adulto con situación de emergencia cardiorrespiratoria, en la unidad de suporte vital avanzado (USA) de atención prehospitalaria móvil (APH). Para la recolección de datos se utilizó la entrevista semi-estructurada que comprendió preguntas acerca del perfil sociodemográfico y profesional, al igual que preguntas dirigidas al tema. La muestra fue constituida por 16 profesionales del USA. Los datos fueron organizados por medio del análisis de contenido según Bardin (1977), identificando cuatro temas: percepciones de los profesionales acerca del APH móvil avanzado, los sentimientos y emociones del equipo frente a la atención de PCR, identificación de los agentes estresantes en situación de PCR y las reacciones de estrés durante en la atención. El equipo relata sus vivencias como un trabajo desafiante y difícil ante las situaciones inesperadas, desconocidas y angustiantes, siendo capaces de percibir satisfacciones personales y realización profesional. Se evidenciaron en las demás categorías analizadas las siguientes expresiones: la búsqueda de conocimiento y constante capacitación técnica, habilidad y agilidad, toma de decisiones, trabajo en equipo, dificultad en lidiar con los sufrimientos de los familiares, manifestaciones emocionales, trabajar con altas temperaturas, dificultad de lidiar con la muerte, manifestando sentimientos de impotencia, frustración y tristeza. Por lo tanto el equipo se enfrenta con la posibilidad de vivir con el sufrimiento psíquico al justificarlo como una necesidad de desarrollar la reflexión y discusión de los aspectos técnicos, científicos y éticos que se refieren a la atención del paciente en PCR en las diferentes situaciones que ocurren durante la atención, buscando así una mejoría en la calidad prestada y en las relaciones interpersonales.

Palabras claves: Prehospitalaria móvil, equipo multiprofesional, paro cardiorrespiratorio, atención de emergencia, estrés.

Fecha Recepción: 17 abril 2006 Fecha Aceptación: 02 septiembre 2008 


\section{INTRODUÇÃO}

A parada cardiorrespiratória (PCR) é a cessação da circulação e da respiração reconhecida pela ausência de batimentos cardíacos e da respiração, em um paciente inconsciente. A interrupção súbita das funções cardiopulmonares constitui um tipo de problema que sempre foi um desafio para a medicina. Representa uma emergência médica extrema, cujos resultados serão a lesão cerebral irreversível e a morte, caso as medidas adequadas para restabelecer do fluxo sangüíneo e a respiração não forem realizadas (American Heart Association, [AHA] 2005).

A PCR pode ser entendida como a situação em que o débito cardíaco é inadequado para a manutenção da vida. O que tem orientado o desenvolvimento científico e tecnológico nas ciências da saúde é a busca da manutenção da vida e a luta contra a morte biológica. Dentre as diversas situações que podem ameaçar a vida dos indivíduos, a mais temida é a PCR (Capovilla, 2002). Assim, para dar suporte adequado a tais situações foi criado o Serviço de Atendimento Móvel de Urgência (SAMU). Este sistema de atendimento pré-hospitalar (APH) foi estruturado e sistematizado, conforme preconiza o modelo francês (Fernandes, 2004 ).

O APH desempenha importante papel na qualidade da assistência oferecida a população. Esta nova modalidade de assistência tem vários objetivos, como o de determinar a forma de melhor resposta à demanda solicitada, através da regulação de todos os chamados e prestar atendimento emergencial no campo préhospitalar, atendimento este que responda às necessidades prementes do paciente crítico (Cyrillo, 2005)

Nesse serviço, médicos e enfermeiros prestam atendimento a casos de maior complexidade, ou seja, de maior gravidade por meio do suporte avançado de vida (USA). Este suporte é oferecido através de ambulâncias equipamentos e instrumental utilizado em uma Unidade de Terapia
Intensiva (UTI); e equipe de médicos, enfermeiros e com condutores de veículos de urgência capacitados. Esta especificação da estrutura do APH móvel e seus componentes são definidos pela Portaria do Ministério da Saúde do Brasil.

Em virtude da constante expectativa de situações de emergência, a freqüência de pacientes graves, possibilidades de mudanças súbitas no estado geral, o ambiente de trabalho caracteriza-se como estressante e gerador de uma atmosfera emocionalmente comprometida, tanto para os profissionais como para os pacientes e seus familiares (Callil \& Paranhos, 2007).

Assim, os profissionais que lidam nesta atividade profissional, vivem em constante desgaste físico e mental, pois se defrontam com os limites e possibilidades para lidar com a dor, sofrimento, morte e ao mesmo tempo a prontidão, raciocínio rápido, a tomada de decisão assertiva e bom condicionamento físico.

Portanto, a temática a ser desenvolvida neste trabalho tem como propósito investigar a vivência de médicos, enfermeiros e condutores de veículos de urgência terrestre de APH móvel, em suporte avançado de vida atuando na assistência ao adulto em situação mais crítica de agravo à saúde, que é a parada cardiorrespiratória (PCR).

O cenário para o desenvolvimento do estudo proposto foi o APH móvel de urgência, na unidade de suporte avançado (USA) da Secretaria Municipal da Saúde de Ribeirão Preto, São Paulo, Brasil e os sujeitos os profissionais que integram esta equipe.

\section{MATERIAL E MÉTODO}

Para o desenvolvimento dessa pesquisa optamos pela realização da metodologia descritiva e exploratória de abordagem qualitativa que responde às questões particulares, num espaço mais profundo das relações, considerando como sujeitos do 
estudo pessoas pertencentes à determinada condições social, com suas crenças, valores e significados (Bogdan \& Biklen, 1997; Minayo, 2000).

Trabalhamos, portanto, com experiências pessoais, relatos individuais descritos com suas próprias palavras, escritas ou faladas, com valorização absoluta dos mesmos, todas as situações e sentimentos vivenciados, sob o ponto de vista da equipe multiprofissional que trabalha na USA do Serviço de Atendimento Móvel de Urgência (SAMU) de Ribeirão Preto.

A USA é uma ambulância tripulada com 3 profissionais, sendo 1 médico, 1 enfermeiro e 1 condutor de veículo de urgência terrestre, todos em turno de plantão. O veículo é equipado para realizar atendimento préhospitalar e/ou transporte inter-hospitalar de alta complexidade, às vítimas de trauma ou situações de emergências clínicas, no município de Ribeirão Preto. Após sua estabilização, as vítimas são encaminhadas aos hospitais da rede pública do Sistema Único de Saúde (SUS), de acordo com o seu nível de complexidade, segundo orientação da Central Única de Regulação Médica (CURM).

A população deste estudo foi composta por 27 profissionais, dos quais 13 são médicos, nove enfermeiros e cinco condutores de veículo de urgência terrestre. A amostra constitui-se por sujeitos que obedeceram ao critério de inclusão, ou seja, concordar em participar do estudo, assinar o termo de consentimento livre e esclarecido, possuir tempo superior a dois anos de trabalhos na USA, autorizar a gravação da entrevista e ter interesse e disponibilidade em ser entrevistado. A amostra foi delineada a partir desses critérios de inclusão, ficando assim constituída por 16 profissionais, dos quais sete médicos, cinco enfermeiros e quatro condutores de veículos de urgência terrestre. A coleta de dados foi realizada por meio de entrevistas, as quais foram gravadas e posteriormente transcritas.

O estudo foi submetido à análise do Comitê de Ética em Pesquisa, da Escola de Enfermagem de Ribeirão Preto da Universidade de São Paulo (EERP-USP) e após sua apreciação e aprovação foi realizada a coleta dos dados.

Após ser estabelecido um contato prévio com os participantes foram agendadas as entrevistas, de acordo com a disponibilidade de cada um. Elas foram realizadas na base da USA, garantindo a privacidade. O período da coleta de dados se desenvolveu nos meses de agosto e setembro de 2005, e as entrevistas tiveram, em média, a duração de trinta minutos.

A entrevista foi constituída por duas partes: a primeira tratou dos aspectos sociodemográficos, da formação profissional e de trabalho desta equipe. A segunda parte foi composta de questões norteadoras por meio de um roteiro semi-estruturado, utilizandose um gravador durante as entrevistas. As questões norteadoras foram: O que é para você trabalhar no atendimento pré-hospitalar móvel? Como é para você quando há um chamado para atender uma situação possível de PCR? Como é o atendimento de uma PCR de adulto, na rua, na estrada ou na residência? Como é essa vivência para você? e Você percebe alterações físicas e/ou psicológicas, em você, no atendimento à $\mathrm{PCR}$ ?

$\mathrm{Na}$ apresentação dos resultados, os sujeitos da pesquisa foram identificados com uma sigla e o respectivo número da entrevista, como por exemplo, Médico-ME; Enfermeiro - EN e Condutor de Veículo de Urgência Terrestre - CVU. E a transcrição das falas seguiu as normas para transcrição, segundo Preti (1993).

\section{RESULTADOS E DISCUSSÃO}

Para análise dos dados coletados, os relatos foram transcritos pela pesquisadora e a análise por sua própria natureza e subjetividade foi fundamentada na abordagem qualitativa, sendo sistematizada conforme a técnica de análise de conteúdo, mais especificamente, a análise temática, proposta por Bardin (1977). 
À medida que os dados foram coletados, procedeu-se à análise dos mesmos. $\mathrm{Na}$ seqüência, ocorreram as etapas de pré-análise, a exploração do material e o tratamento dos resultados. Inicialmente, procedemos às transcrições das entrevistas e, posteriormente, realizamos a sua leitura exaustiva, identificando os códigos semelhantes. Estes foram agrupados em quatro categorias principais, possibilitando a compreensão da vivência das atividades dessa equipe multiprofissional que atua na USA: Percepções sobre o APH móvel avançado, os sentimentos e emoções da equipe multiprofissional de APH móvel avançado frente ao atendimento à PCR, identificação dos agentes estressores ao atendimento à PCR e as reações de estresse no atendimento à PCR.

No presente trabalho procuramos identificar no conteúdo das entrevistas da equipe multiprofissional, as unidades de codificação por meio de frases que indicassem características da dinâmica do atendimento avançado pré-hospitalar móvel ao adulto na situação de parada cardiorrespiratória (PCR).

Quanto ao perfil sociodemográfico e profissional dos condutores de veículos de da USA do SAMU de Ribeirão Preto, observouse que há uma predominância da faixa etária de 35-43 anos, do sexo masculino, e estado civil variável, sendo dois casados, um viúvo e um em união estável (não casado); quanto a religião todos se definiram católicos. Com relação ao número de filhos notamos que todos têm filhos, variando de um a dois filhos. Em relação a formação profissional, o nível de escolaridade dos condutores variou desde $1^{\circ}$ Grau incompleto até $2^{\circ}$ Grau completo.

Analisando a questão do exercício profissional, os condutores estão entre 15 - 25 anos de habilitação profissional como motorista de veículos de transporte de pacientes. Esta prática é regulamentada com Curso de Direção Defensiva para ambulância, de acordo com a legislação do Código Nacional de Trânsito do Brasil, atendendo a
Portaria do Ministério da Saúde 2048/2002 (Ministerio da Saúde Brasil, 2002).

O tempo de atuação desses profissionais na USA está entre 9-14 anos, e realizam uma carga horária de trabalho de 44 horas semanais, em escala de serviço mensal de 12 X36 horas, sendo dois deles no horário diurno, dois no horário noturno e um folguista, segundo relato dos mesmos.

Quanto ao motivo que os levou a trabalhar na USA foi a vontade de conhecer e desenvolver um novo serviço, além do convite da chefia. Ainda, observamos que todos os condutores referiram participação em eventos científicos, nos últimos três anos.

Com relação ao perfil sociodemográfico e profissional dos enfermeiros da USA do SAMU de Ribeirão Preto, verificamos que a faixa etária variou de 39-47 anos; quanto ao gênero é o feminino, a religião católica, estado civil variável, sendo duas casadas, duas divorciadas e uma solteira. Quanto ao número de filhos, apenas uma delas não possui filhos, as demais tem filhos variando em número de um a dois. Quanto a formação profissional, uma enfermeira com possui Especialização em Saúde Pública e Enfermagem em UTI, uma com Especialização em Administração Hospitalar, Enfermagem em UTI e Mestrado, uma com Especialização em Saúde Pública, Licenciatura e Administração, uma com Especialização em Enfermagem do Trabalho, Enfermagem do Trauma e Mestrado e uma com Especialização em Enfermagem Pediátrica.

Os anos de formação dessas profissionais são variáveis, entre 17 - 22 anos de trabalho. O tempo de atuação no APH móvel dos enfermeiros entrevistados está entre 8-10 anos nesse tipo de atividade.

No que se refere a carga horária de serviço na USA, do SAMU observamos que houve uma variação entre 20-40 horas semanais, sendo que uma das enfermeiras ainda exerce a função de coordenação de enfermagem do próprio SAMU.

Com relação ao motivo destas enfermeiras 
irem trabalhar na USA foi interesse e identificação com as atividades desenvolvidas, além da possibilidade na época, de aumentar a carga horária de trabalho de 20 horas semanais para 40 horas semanais para a maioria delas, significando uma melhora no aspecto financeiro, segundo suas informações. Todas são unânimes em manifestar prazer e realização profissional nesse tipo de assistência em situação de urgência.

As enfermeiras que trabalham em situações emergenciais tem que estar em constante atualização e capacitação, o que neste grupo foi bem evidenciado, sendo que a maioria se preocupa em participar de eventos científicos para atualização. É importante ressaltar, que no grupo de enfermeiros investigados dois tem pós-graduação stricto sensu (Mestrado), que visam a capacitação e pesquisa na área de urgência e emergência, sugerindo envolvimento e comprometimento com o tipo de atividade desenvolvida na prática assistencial.

A equipe de médicos da USA do APH móvel do SAMU de Ribeirão Preto predomina a faixa etária de 35-49 anos, estado civil casado, religião católica, a maioria com filhos em número de um e três. Quanto à formação profissional, um com Especialização em Anestesiologia e Doutorado, um com Especialização em Cirurgia de Cabeça e Pescoço e Mestrado, um com Especialização em Terapia Intensiva e Doutorado, um com Especialização em Cirurgia Vascular, um com Especialização em Cirurgia Geral e Vascular e cursando o mestrado, um com Especialização em Cirurgia de Cabeça e Pescoço, e um especializado em Cardiologia. Os anos de formação desta equipe são variáveis em 1025 anos.

O período de atuação na USA dos médicos entrevistados está entre 3-10 anos, sendo a carga horária variável em 20 a 40 horas semanais. Com relação ao motivo que os levou a trabalhar neste tipo de atividade, nota-se na sua maioria a identificação com o tipo de trabalho e assistência.

É relevante o aspecto da participação desses profissionais em eventos científicos de atualização em urgência e emergência. Destacam-se inclusive os aspectos de formação em pós-graduação Strictu sensu de três médicos evidenciando interesse de constante capacitação e possibilidade de desenvolvimento para pesquisa, colaborando com o crescimento científico na área emergencialista.

Com relação à qualificação profissional em emergência, a Portaria do Ministério da Saúde 2048/2002 (Ministerio da Saude, 2002) destaca a necessidade de treinamento voltado à melhoria da qualidade da informação referente à vigilância epidemiológica por causas externas. Nos cursos de graduação da área da saúde, a atenção na área de emergência é insuficiente sendo necessária a complementação com cursos de formação, capacitação e educação permanente dos recursos humanos.

Uma vez caracterizado o perfil da equipe passaremos a apresentar a análise do objeto principal desse estudo, procurando compreender e descrever os depoimentos que emergiram nas entrevistas.

Após a leitura flutuante e análise categorial, os temas emergentes foram agrupados em quatro categorias e dez subcategorias, as quais serão discutidas nesse estudo. As categorias identificadas foram: o trabalho no APH móvel avançado; os sentimentos e emoções da equipe multiprofissional de APH móvel Avançado frente ao atendimento à PCR; a identificação e reações acerca dos agentes estressores no atendimento a PCR.

$\mathrm{Na}$ categoria, percepções sobre o trabalho no APH móvel avançado foi identidificado duas subcategorias, o desafio/satisfação pessoal e realização profissional e capacitação permanente. A equipe multiprofissional relatou que trabalhar no APH móvel avançado é um desafio com dificuldades e riscos, mas com a possibilidade de satisfação pessoal, pelo fato de gostarem desse tipo de atividade, ou seja, trabalhar com urgência e emergência.

As falas revelaram que o trabalho no APH móvel avançado traz a necessidade de capacitação 
permanente, objetivando a qualidade na assistência, como nos relatos a seguir: ...prá mim é um grande desafio ... devido as diferentes ocorrências ... diferentes tipos de atendimento e a própria característica do serviço...(EN10); primeiramente é uma ... realização profissional visto que eu gosto desse serviço de urgência e emergência ... e além do que é uma ... atividade médica sem muita rotina ... com eventos que não se repetem... o que deixa o trabalho motivante ... estimulante por si só (...) ( ME3); - é muito bom ... é muita satisfação pessoal ... acima de todas as dificuldades... mas é um blende de emoção ... de tristeza ...de loucura (risos) ... acho que é um pouco de tudo ... mas é muita satisfação apesar de TODAS AS DIFICULDADES (...) (EN14); aqui a gente trabalha salvando vidas ... então eu acho que me empenhei muito em aprender, procurar sempre tá pesquisando ... sempre tá perguntando ... sempre tá sabendo o que tá acontecendo durante os atendimentos ... eu acho que isso fez bem prá mim (...) (CVU13); éa obrigatoriedade de prestar uma assistência qualificada ... estar capacitado ... ajudando as pessoas num momento de grande sofrimento em sua vida ... com alteração de toda a sua rotina diária (...) (EN12).

A categoria com relação aos sentimentos e emoções da equipe multiprofissional frente ao atendimento à PCR na USA de APH móvel foi subcategorizada nos aspectos angústia e ansiedade pelo desconhecido, envolvimento emocional, presença de populares/família no local de atendimento à PCR e conhecimento técnico/trabalho em equipe. Os relatos mostram que o potencial de ansiedade mantém-se fisiologicamente presente e carrega consigo o sentimento do medo, sua sombra inseparável. Faz parte da natureza humana certos sentimentos determinados pelo perigo, pela ameaça, pelo desconhecido e pela perspectiva de sofrimento.

Os profissionais que trabalham nesse contexto vivenciam os mais diversos sentimentos e emoções, que permeiam os variados tipos de atendimentos. Sempre que alguma situação adversa é detectada, as intervenções são quase imediatas. Nesse ambiente, o tecnicismo assume um papel relevante na prestação da assistência e o imediatismo das atividades determina a sua qualificação. Dessa forma, o comportamento puramente técnico, muitas vezes, leva a equipe a sobrepor seus conhecimentos aos do paciente e de sua família, contribuindo ainda mais para o desmantelamento das relações interpessoais equipe da USA-família do paciente .

No serviço de emergência essa relação é rápida pela natureza do encontro entre o paciente crítico e a equipe de saúde, mas é aprofundada e expressada por meio dos sentimentos que afloram na situação de emergência (Condorimay, 2003).

Os relatos a seguir evidenciam esses vários sentimentos e emoções vivenciados em situações de PCR como a angústia, o medo do desconhecido, o envolvimento emocional, presença de populares ou familiares no local do agravo, o trabalho em equipe: “... desafiar o desconhecido ... é ... talvez a possivel sensação de incapacidade de não conseguir (...) $o$ atendimento em si passa a ser protocolado e não trás nenhum estresse na sua execução ... porém as adversidades dos locais ... residências ... ruas ... estradas ... é a causa de grande estresse ... grande angústia e ansiedade ... pois por muitas vezes as situações são muito inesperadas (...)" (EN12); “... é inicialmente havia um envolvimento até sentimental ... hoje já há um lado muito profissional ... você vai tá analisando se é uma parada e o que eu posso fazer por ela (...)"(ME5); “...existe um envolvimento emocional e muitas vezes é sublimado ou ... racionalizado até prá não sofrer ... porque não é fácil (...)” (EN14); “... a família sempre é um fator de tumultuar o atendimento ... e assim a pressão mesmo prá você resolver o caso ... se você está fazendo corretamente” (ME2); “...a gente tem que trabalhar em cima daquilo da seqüencia de atendimento ... em equipe prá poder salvar aquela vida (...)" (CVU13); “... é uma vivência de muitos anos nesse tipo de atendimento ... e muito tempo estudando ... conhecendo a equipe de trabalho ... eu fico mais tranqüila (...)" (EN10). 
$\mathrm{Na}$ terceira categoria apresenta-se a identificação de agentes estressores na situação de PCR e compreendem as seguintes subcategorias situação de risco de morte/emergência, a morte como sentimento de frustração e tristeza e temperatura ambiente/esforço físico.

A compreensão da realidade vivenciada pela equipe multiprofissional que atua na USA requer a identificação dos fatores que dificultam a sua atuação, os quais podem estar contribuindo para a despersonalização do atendimento ao paciente e sua família gerando o distanciamento, o estresse e o sofrimento da equipe.

Nos depoimentos analisados dos entrevistados nessa categoria, foram identificados a própria evidência de uma urgência/emergência, a morte com sentimento de frustração e tristeza, e a temperatura ambiente, como descrito a seguir: “... você sabe que a situação é crítica e o paciente precisa de assistência total de qualidade e condições naquele instante (...)”(EN15); “... quando há uma perda de vida ... tem um contexto pessoal de frustração profissional e existe um estresse emocional (...)” (ME7); “... depois do atendimento vem o sentimento de frustração ... tristeza ... você não conseguiu realizar bem o serviço ... o paciente tinha uma condição boa ... era jovem ... que as vezes você não conseguiu desempenhar um bom papel ... então essas alterações vem depois (...)" (ME8); “... existe um stress físico devido as manobras de reanimação ... dependendo do local onde tá a vítima ... com sol calor ... não é fácil ... então existe um pouco de stress físico por causa disso (...)" (ME11).

Por fim, na categoria sobre reações de estresse no atendimento à PCR foi identificada uma única subcategoria alterações físicas e/ ou psicológicas. Na literatura a preocupação científica com a questão do estresse reside na sua provável relação com o adoecimento ou sofrimento que ele provoca (Pegoraro, 2002).

Os sintomas físicos mais comuns são: fadiga, dores de cabeça, insônia, dores no corpo, palpitações, alterações intestinais, náusea, tremores, extremidades frias e resfriados cons- tantes. Entre os sintomas psíquicos, mentais e emocionais, encontram-se a diminuição da concentração e memória, indecisão, confusão, perda do senso de humor, ansiedade, nervosismo, depressão, raiva, frustração, preocupação, medo, irritabilidade e impaciência (Figueiras \& Hippert, 2002).

De acordo com os depoimentos, está claro que mesmo vivenciando muito tempo, diversas situações de emergência, em especial, nos momentos de atendimento em PCR, a maioria dos profissionais ainda demonstram reações físicas e/ou psicológicas, como ansiedade, taquicardia, sudorese, tremores, náuseas, diarréia, diante das, como mostra as falas: “... a gente fica nervoso ... estressado ... é estressante um atendimento de PCR (...)"(CVU6); “... sinto taquicardia ... sudorese ... as vezes náuseas ... e a sensação de diarréia pós estresse... percebe ... tudo isso realmente acontece (...)" (ME7); “... existe uma taquicardia associada a sudorese ... existe uma tentativa de racionalizar o sentimento por meio de fuga de pensamentos totalmente diferentes ... adversos daquela situação ... e as vezes a gente percebe períodos de pequenas explosões por coisas bobas ... as vezes você passa por momentos de raiva interna (...)" (EN12).

\section{COMENTÁRIO}

\section{Implicações para prática}

A metodologia utilizada permitiu destacar, a partir dos dados analisados, que a equipe multiprofissional enfrenta variados sentimentos que permeiam as situações na assistência no evento da PCR/RCP, o que demonstrou ser característica própria da dinâmica desse tipo de trabalho.

O conjunto de categorias propiciou o conhecimento das necessidades de uma equipe de trabalho no contexto pré-hospitalar de urgência e emergência. Essas necessidades são vistas por sentimentos relacionados ao lidar com situações inesperadas, vivenciar emoções no limite e ambíguas, o medo do desconheci- 
do, a possibilidade do envolvimento emocional, o contato com familiares e populares, com a morte, o trabalho e integração da equipe, e por fim, as reações físicas e psicológicas que surgem diante da situação.

Tendo em vista a temática desenvolvida, não cabem aqui generalizações, mas sim, a tentativa de compreender como essa equipe multiprofissional atua num ambiente de trabalho assistencial de emergência em situação de PCR.

O evento da PCR atendida no APH móvel avançado gera nos profissionais estresse, ansiedade e insegurança, evidenciando a questão do sofrimento psíquico, um processo profissional negativo e frustrante.

As implicações científicas observadas nesse estudo sugerem concretização de ações primordiais para o desenvolvimento, qualificação e suporte psicossocial a equipe atuante neste contexto.

Com esta pesquisa esperamos oferecer subsídios para que a equipe de APH possa pensar no seu ambiente de trabalho como um espaço de prazer e despertar para os cuidados com situações estressoras. Possibilita também uma dimensão transformadora no âmbito da prática no atendimento de emergência na PCR, pois o conhecimento à cerca dos sentimentos vivenciados pela equipe nesse contexto propiciará atitudes em seu comportamento, em relação não só ao paciente, como ao desenvolvimento de uma prática mais saudável. $\mathrm{O}$ impacto desta dimensão transformadora nos permite dar encaminhamentos no sentido de buscar suporte terapêutico propiciando qualidade de vida profissional.

\section{REFERÊNCIAS}

American Heart Association. AHA (2005). Guidelines for Cardiopulmonary Resuscitation and Emergency Cardiovascular Care. International Consensus on Science. Circulation, 112, p.IV1-IV-211.

Bardin, L. (1977). Análise de conteúdo. Lisboa: Edições 70.
Bogdan, R. \& Biklen, S. (1997). Investigação qualitativa em educação. Editora Porto.

Callil, A.M. \& Paranhos, W.Y. (2007). O Enfermeiro e as Situações de Emergência. São Paulo: Editora Atheneu.

Capovilla, N.C. (2002). Ressuscitação cardiorrespiratória: uma análise do processo ensino/ aprendizagem nas universidades públicas estaduais paulistas. 2002. Dissertação de Mestrado. Faculdade de Ciências Médicas, Universidade Estadual de Campinas/UNICAMP (SP), Brasil.

Condorimay, Y. R. T. (2003). Vivências da enfermeira na assistência à criança em situação de emergência - parada cardiorrespiratória. Dissertação de Mestrado. Escola de Enfermagem de Ribeirão Preto, Universidade de São Paulo. Ribeirão Preto (SP), Brasil.

Cyrillo,R.M.Z.(2005).Diagnósticos deenfermagem no Atendimento Pré-hospitalar Avançado Móvel em vítimas de trauma. Dissertação de Mestrado. Escola de Enfermagem de Ribeirão Preto, Universidade de São Paulo. Ribeirão Preto (SP), Brasil.

Fernandes, R. J. (2004). Caracterização da atenção pré-hospitalar móvel da Secretaria do Município de Ribeirão Preto - SP. Dissertação de Mestrado. Escola de Enfermagem de Ribeirão Preto, Universidade de São Paulo. Ribeirão Preto (SP), Brasil.

Figueiras, J. C. \& Hippert, M. I. (2002). Estresse. In: Jacques, M.G., Codo, W. organizadores. Saúde mental \& trabalho. Petrópolis (RJ): Vozes.

Minayo, M. C.S. (2000). O desafio do conhecimento: pesquisa qualitativa em saúde. $7^{\text {a }}$. Ed. São Paulo (SP): Hucitec-Abrasco.

Ministério da Saúde Brasil (2002). Regulamento técnico dos sistemas de urgência e emergência. Portaria no 2048/GM de 05 de novembro de 2002. Recuperado el: 20 junho 2003. Disponível em: http://www.saude.gov.br/portarias/2002.

Pegoraro, I. B. (2002). Níveis de stress em trabalhadores de unidades distritais de saúde; uma realidade preocupante. Dissertação de Mestrado. Escola de Enfermagem de Ribeirão Preto, Universidade de São Paulo. Ribeirão Preto (SP), Brasil.

Preti, D. (1993).Análise de textos orais. FFLCH/ USP. p.103-127. 